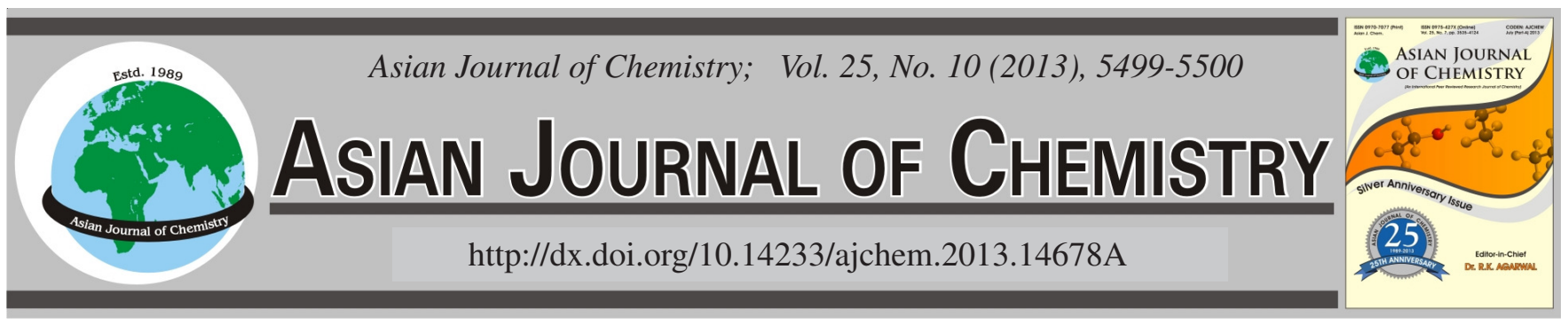

NOTE

\title{
Hydrothermal Synthesis of 1D Zn(II) Coordination Polymer
}

BIN LI

Institute of Chemical Engineering and Environment, Wei Fang University of Science and Technology, Shandong 262700, P.R. China

Corresponding author: E-mail: whyull@yeah.net

(Received: 15 October 2012;

Accepted: 15 April 2013)

AJC-13242

\begin{abstract}
One new $\mathrm{Zn}(\mathrm{II})$ compound $[\mathrm{Zn}(\mathrm{L})(1,10-\text { phen })]_{\mathrm{n}}\left[\mathrm{H}_{2} \mathrm{~L}=4\right.$,4-(isopropylidene)-bis(benzoic acid) and 1,10-phen = 1,10-phenanthroline] has been successfully synthesized. This compound shows a one-dimensional chain. The carboxylate groups in present compound adopt a bischelating coordination mode.
\end{abstract}

Key Words: Coordination polymer, Crystal structure.

The current interest in polymeric coordination networks is rapidly expanding not only for their potential applications in catalysis, molecular adsorption, magnetism, non-linear optics and molecular sensing, but also for their intriguing variety of topologies ${ }^{1-4}$. Although the rapid progress in metalorganic frameworks has been made, it is also a great challenge to rationally prepare and control the structures and composition of target products in crystal engineering because of the difficult prediction of either the composition or the structure of the reaction product.

All reagent and solvents employed were commercially available and used as received without further purification.

Preparation of compound: A mixture of 4,4(isopropylidene)-bis(benzoic acid) $(1 \mathrm{mmol}), \mathrm{Zn}(\mathrm{OAc})_{2} \cdot 2 \mathrm{H}_{2} \mathrm{O}$ (1 mmol ), 1,10-phenanthroline (1 mmol) and distilled water $(15 \mathrm{~mL})$ was heated in a $25 \mathrm{~mL}$ stainless steel reactor with a Teflon liner $160^{\circ} \mathrm{C}$ for $96 \mathrm{~h}$, followed by slow cooling to room temperature. Yellow crystals of the compound formed.
X-crystallography: Suitable single crystals were selected under a polarizing microscope and fixed with epoxy cement on fine glass fibers which were mounted on a Bruker Smart 1000 CCD diffractometer with a $\mathrm{MoK}_{\alpha}$ radiation $(\lambda=0.71073$ $\AA$ ) at 293(2) K. The hydrogen atoms bound to carbon were located by geometrically calculations. All non-hydrogen atoms were refined by full-matrix least-squares techniques. All calculations were performed by the SHELXTL 97 program $^{5}$. The crystallographic data and experimental details of structural analyses for coordination polymers are summarized in Table-1.

Structure description: In compound 1, Zn (II) atom is coordinated to four oxygen atoms from two L ligands and two nitrogen atoms from 1,10-phenanthroline ligand. In compound the carboxylate groups adopt a bis-chelating coordinated modes which lead to form a 1D chain structure (Fig. 1).

TABLE-1

CRYSTALLOGRAPHIC DATA AND STRUCTURE REFINEMENT SUMMARY FOR COMPLEX

\begin{tabular}{ll}
\hline Empirical formula & $\mathrm{C}_{29} \mathrm{H}_{22} \mathrm{~N}_{2} \mathrm{O}_{4} \mathrm{Zn}$ \\
Formula weight & 527.88 \\
Crystal system space group & Orthorhombic, Pbca \\
& $\mathrm{a}=13.828(5) \AA$ \\
Unit cell dimensions & $\mathrm{b}=10.833(5) \AA$ \\
& $\mathrm{c}=28.728(5) \AA$ \\
& $\beta=90^{\circ}$ \\
Volume $\left(\AA^{3}\right)$ & $4303(3)$ \\
$\theta$ Range for data collection & $1.42-27.53$ \\
Final R indices $[\mathrm{I}>2 \sigma(\mathrm{I})]$ & $\mathrm{R}_{1}=0.0470, \mathrm{wR}_{2}=0.1387$ \\
\hline
\end{tabular}

$\begin{array}{ll}\text { Z, Calculated density }\left(\mathrm{mg} / \mathrm{m}^{3}\right) & 8,1.584 \\ \text { Absorption coefficient }\left(\mathrm{mm}^{-1}\right) & 1.869 \\ \mathrm{~F}(000) & 2017 \\ & -17 \leq \mathrm{h} \leq 17 \\ \text { Limiting indices } & -10 \leq \mathrm{k} \leq 14 \\ & -37 \leq 1 \leq 37 \\ & \\ \text { Largest diff. peak and hole }\left(\mathrm{e} / \AA^{3}\right) & 0.341 \text { and }-0.727 \\ \text { Goodness-of-fit on } F^{2} & 0.897 \\ \mathrm{R} \text { indices (all data) } & \mathrm{R}_{1}=0.0804, \mathrm{wR}_{2}=0.1660\end{array}$




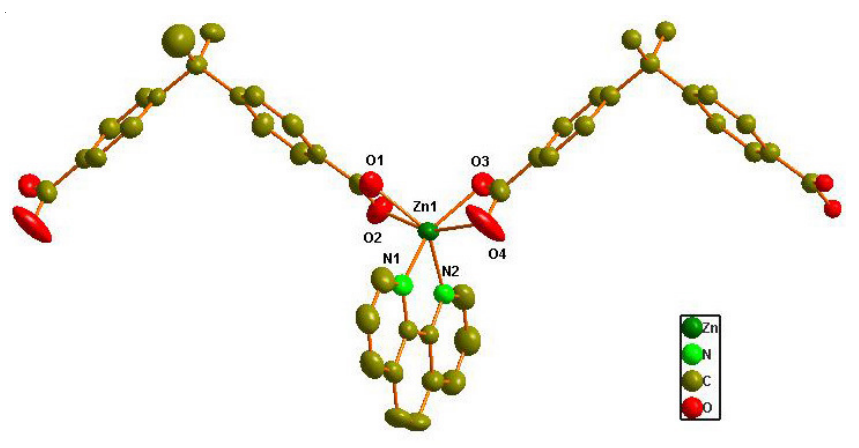

Fig. 1. Molecular structure of 1-D Zn(II) coordination polymer at $30 \%$ probability displacement ellipsoids

\section{REFERENCES}

1. B.O. Patrick, C.L. Stevens, A. Storr and R.C.Thompson, Polyhedron, 24, 2242 (2005).

2. Y.H. Wen, J.K. Cheng, Y.L. Feng, J. Zhang, Z.L. Li and Y.G. Yao, Inorg. Chim. Acta, 358, 3347 (2005).

3. X.L. Wang, C. Qin, E.B. Wang and L. Xu, J. Mol. Struct., 749, 45 (2005).

4. S.R. Batten and K.S. Murray, Coord. Chem. Rev., 246, 103 (2003).

5. G.M. Sheldrick, SHELXTL97, Program for the Refinement of Crystal Structure, University of Gottingen, Germany (1997). 